\title{
EXPERIMENTAL EVALUATION OF DAMAGE INFLUENCE ON BUCKLING PERFORMANCE OF STIFFENED CFRP SHELLS
}

\author{
EKSPERIMENTĀLS NOVĒRTĒJUMS BOJĀJUMU IETEKMEI UZ RIBOTU OGLEKL̨A \\ ŠĶIEDRAS KOMPOZĪTO ČAULU NOTURĪBU
}

\author{
O. Ozolinšs, K. Dzelzītis, E. Eglīitis
}

Keywords: buckling, post-buckling, delamination, non-destructive inspections

\section{Introduction}

Delamination type failures are often observed in carbon-epoxy composites, where catastrophic failure is generally preceded by constituent level damage accumulation. Out-of-plane loading such as internal pressure in a composite fuselage or out-of-plane deformations in compression-loaded post-buckled panel may lead to debonding of the frame or stiffener from the panel. Therefore, much research has been conducted on delamination initiation and propagation in composite structures. Extensive research on postbuckling delamination of stiffened composite panels has been performed at California Institute of Technology, USA, in the 80ties. S. Natsiavas et al. carried out a numerical and experimental study on a stiffened composite panel subjected to in-plane compression to the collapse level [1]. The experimental part of the investigation has been performed on a specimen provided by NASA Langley with dimensions of $177.8 \mathrm{~mm}$ by $152.4 \mathrm{~mm}$ and total thickness of $2.24 \mathrm{~mm}$. The stiffener had half of the thickness of the panel and was located at a side of the specimen. A displacement controlled uniaxial compression loading was applied to the panel, and in-plane and out-of-plane displacements at selected locations were monitored. The load-displacement response was recorded until the specimen failed in the post-buckling region. MSC/NASTRAN computer code was used for the numerical analysis. The structure was modelled using CQUAD4 plate elements. The experimentally tested specimen failed due to delamination near the longitudinal supports providing simply supported boundary conditions rather than the panel/stiffener separation. A significant discrepancy between the experimental and numerical results was observed. However, both experimental and numerical results show that the stiffened panel can exhibit a significant post-buckling strength. From the experimental data, the failure load was about three times higher than the buckling load.

K.-F. Nilsson et al. preformed a numerical and experimental investigation of delamination buckling and growth in slender composite panels loaded in compression [2]. The investigated panels consisted of 35 plies of cross-ply lay-up with artificially embedded delamination at different depths. The tests consistently showed that delaminated panels failed by delamination growth slightly below the global buckling load of undamaged panel, while the undamaged panels failed in compression at global buckling. Features seen in the tests were also captured in the computational analysis, and excellent agreement with tests was found for loads at which delaminated members buckle, the load for onset of delamination growth and the evolution of delamination.

A new model for the prediction of delamination growth and post-buckling behaviour of composite plates with embedded delamination has been developed by P. Gaudenzi et al. at Universita di Roma La Sapienza [3]. The incremental continuation method has been modified for the analysis of the non-linear behaviour of damaged composites. Modified virtual crack closure technique and a general formulation of the continuation method is used for evaluation of the delamination growth. The comparison of the numerical results to the available experimental data shows the effectiveness of the proposed method. 
More recently, A. Tafreshi from the University of Manchester has performed a series of finite element analyses on the delaminated composite cylindrical shells subjected to combined axial compression and externals pressure $[4,5]$. The interactive buckling curves and post-buckling response of the shells has been obtained, and in the analysis of post-buckling delaminations, the virtual crack closure technique has been used to find the distribution of the strain energy release rate along the delamination front. The results show, that under pure bending, laminated cylindrical shells are more sensitive to the presence of delamination, than they are under pure axial compression.

The present investigation deals with evaluation of the buckling performance of two stiffened CFRP panels, one with and the other without delaminations. One of the two torsion box face panels has been damaged during torsion/buckling testing at POLIMI, Milan [6] and has been sent to RTU for ultrasonic inspections of hidden delamination. Additionally, buckling tests of damaged and non-damaged panels have been carried out. Quantitative comparison in terms of first buckling load and maximum load in postbuckling region are performed to assess the amount of damage, which is acceptable within the safe exploitation range of panel load carrying capacity. The obtained results can be used as guidelines for safe structural design of stiffened composite structures, tolerant to damage that can occur due to impacts, overload or some other unexpected circumstances.

\section{Test specimens}

The whole COCOMAT BOX A [7, 8] consisting of two face panels incorporating 5 ribs each, connected by the flat side panels, was disassembled at POLIMI, Milan and delivered to RTU. COCOMAT BOX 6A and $6 \mathrm{~B}$ panels manufactured by IAI and tested under torsion loading at TECHNION/POLIMI were provided to RTU for the non-destructive ultrasonic inspection to detect the hidden delamination damage caused by torsion testing, see Fig. 1.

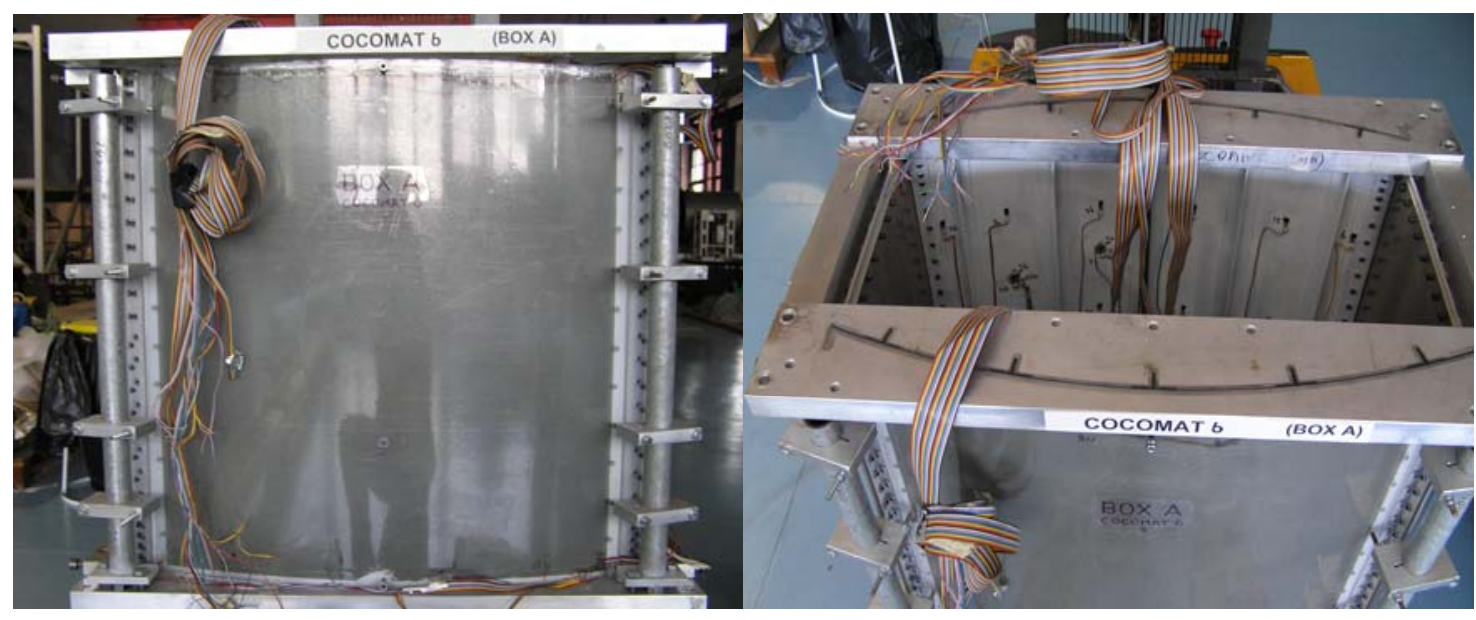

Fig. 1

COCOMAT torsion box consisting of two face stiffened panels, connected by two flat side panels.

\section{Ultrasonic inspections}

An experimental set-up presented in Fig. 2 is used in this study and consists of a computer-controlled ultrasonic flaw detector USPC 3010 Industrial, an immersion probe of $10 \mathrm{MHz}$, a glass water tank, and a stepper motor-controlled XYZ-manipulator. An industrial PC with Hillgus software provides manipulation 
and settings of the ultrasonic flaw detector, data storage and imaging of test results for A-, B-, C-, and Dscans.

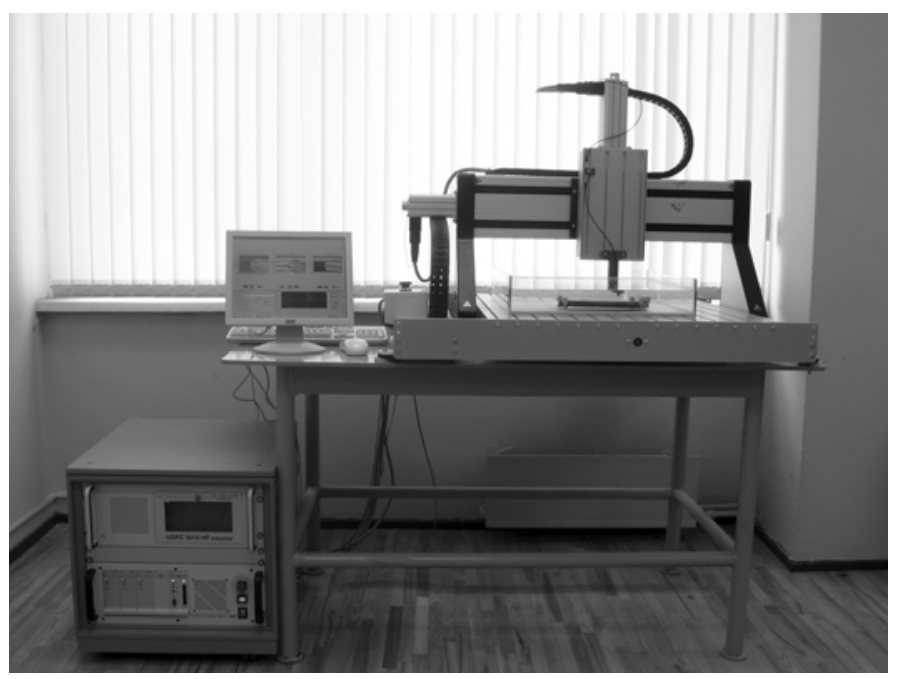

Fig. 2

USPC 3010 ultrasonic inspection equipment.

Scanning head holder with manually adjustable head angle, as seen in Fig. 3, was constructed and manufactured for this task. The original one was capable of holding head in vertical direction and scanning flat surfaces only. The new head holder allows scanning curved panels as well because of the adjustable head that keeps the angle perpendicular to the scanning surface. The manufactured scanning head holder allows head working angles from $-10^{\circ}$ to $+90^{\circ}$ from its original vertical position.

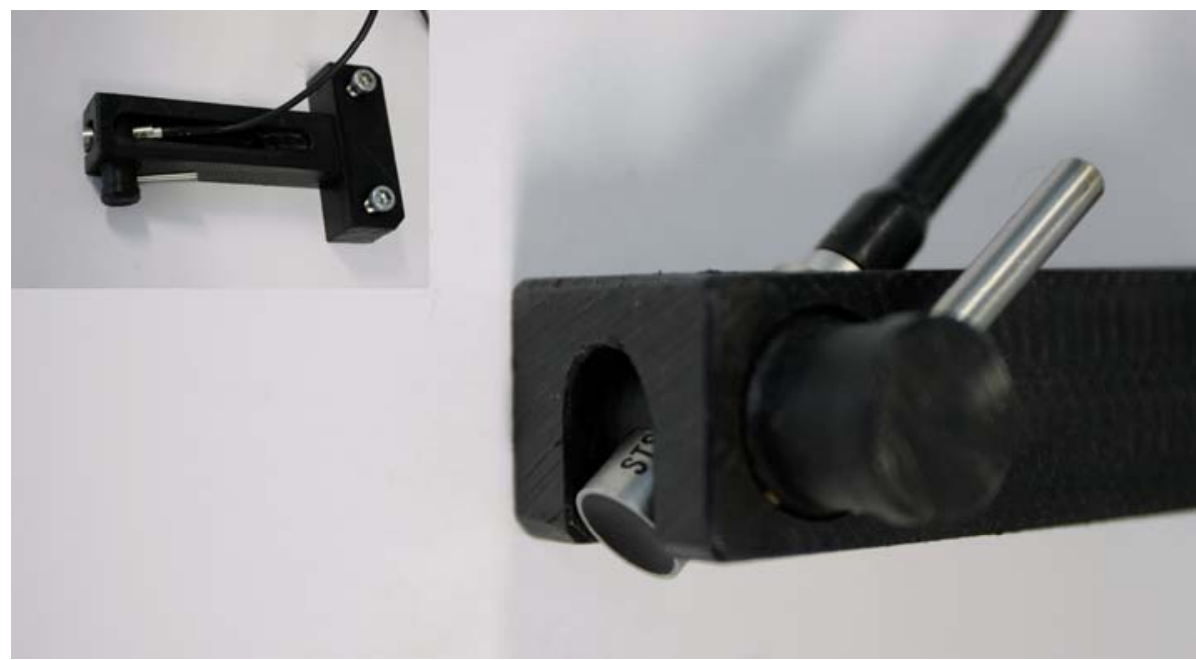

Fig. 3

Ultrasonic scanning head holder with head rotation capabilities.

The front of the panel has been scanned and the response graphs of backwall, defect depth and flaw echo are presented in Fig. 4 to Fig. 6 . The scanned area of the panel has been trimmed by $5 \mathrm{~mm}$ so the ultrasonic probe does not hit the sidewalls of the panel. 


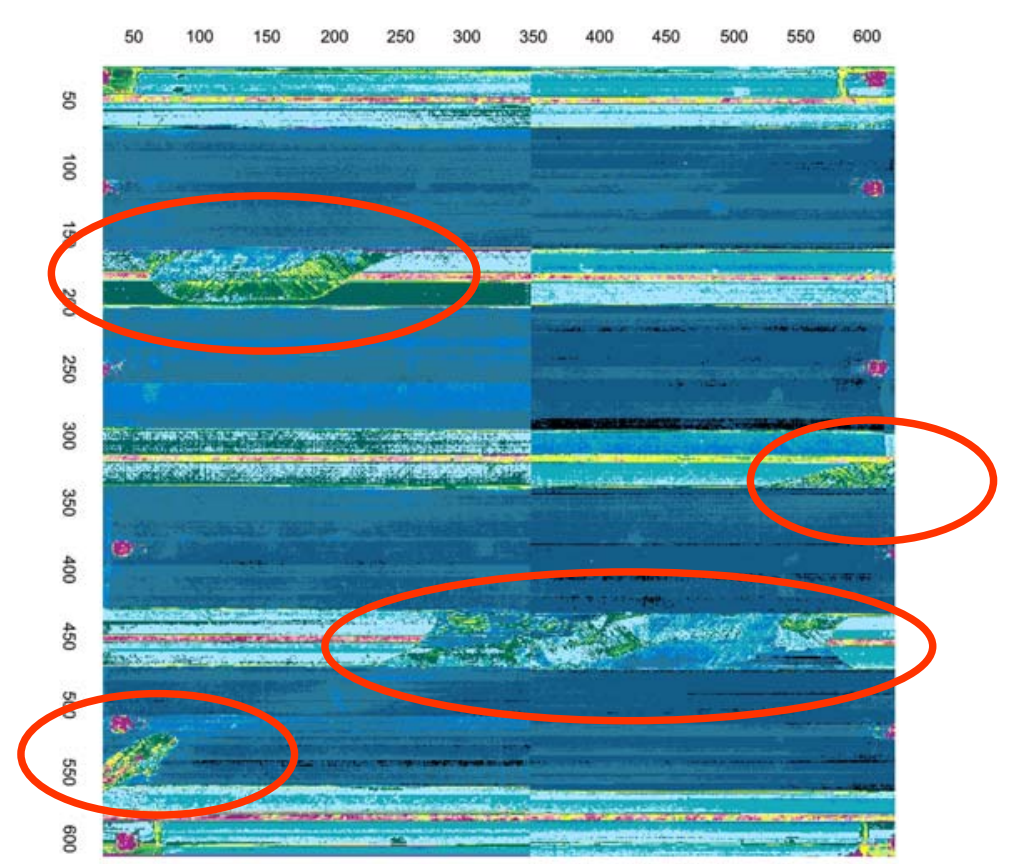

Fig. 4

Ultrasonic backwall response of the COCOMAT 6A panel

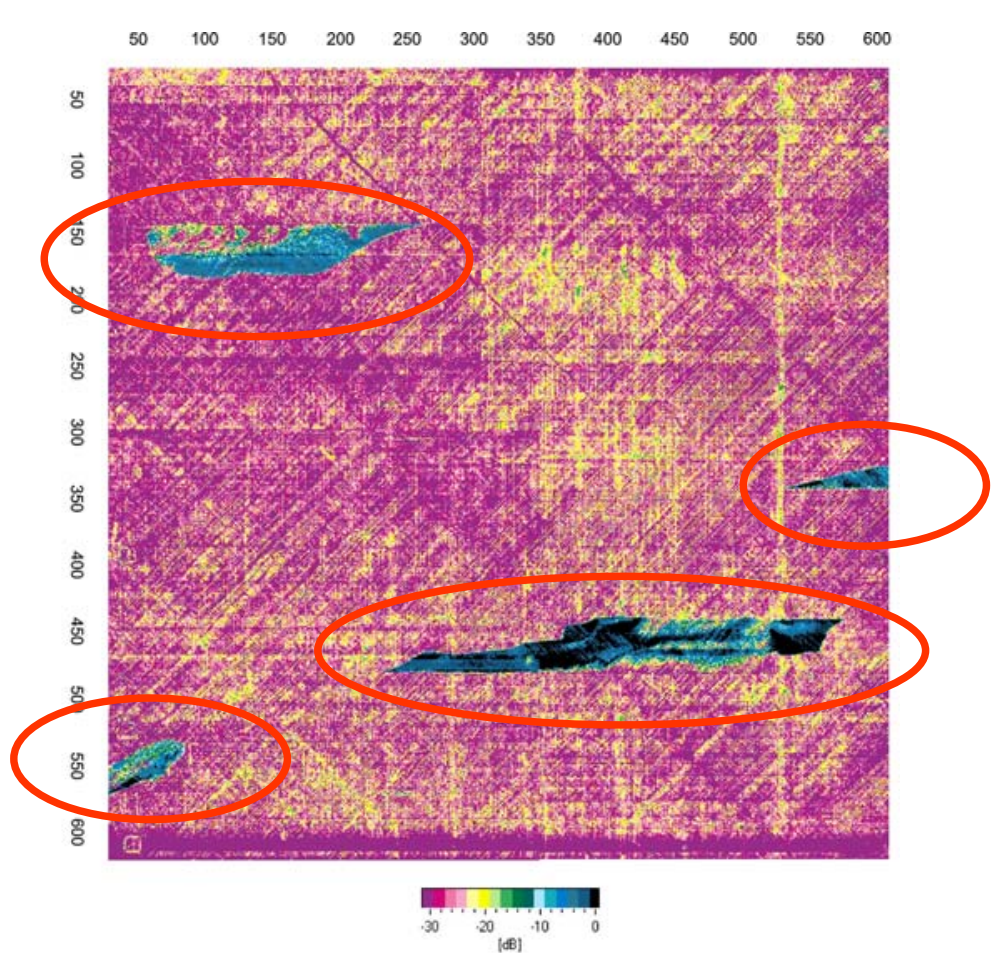

Fig. 5

Ultrasonic flow echo response of the COCOMAT 6A panel 
According to the acquired ultrasonic responses (Fig. 4 to Fig. 6), explicit skin-stiffener delamination has occurred. Visual inspection approved that the second stiffener has detached from the skin of the panel. Detailed pictures of the delaminated area between the skin and stiffeners are shown in Fig. 7.

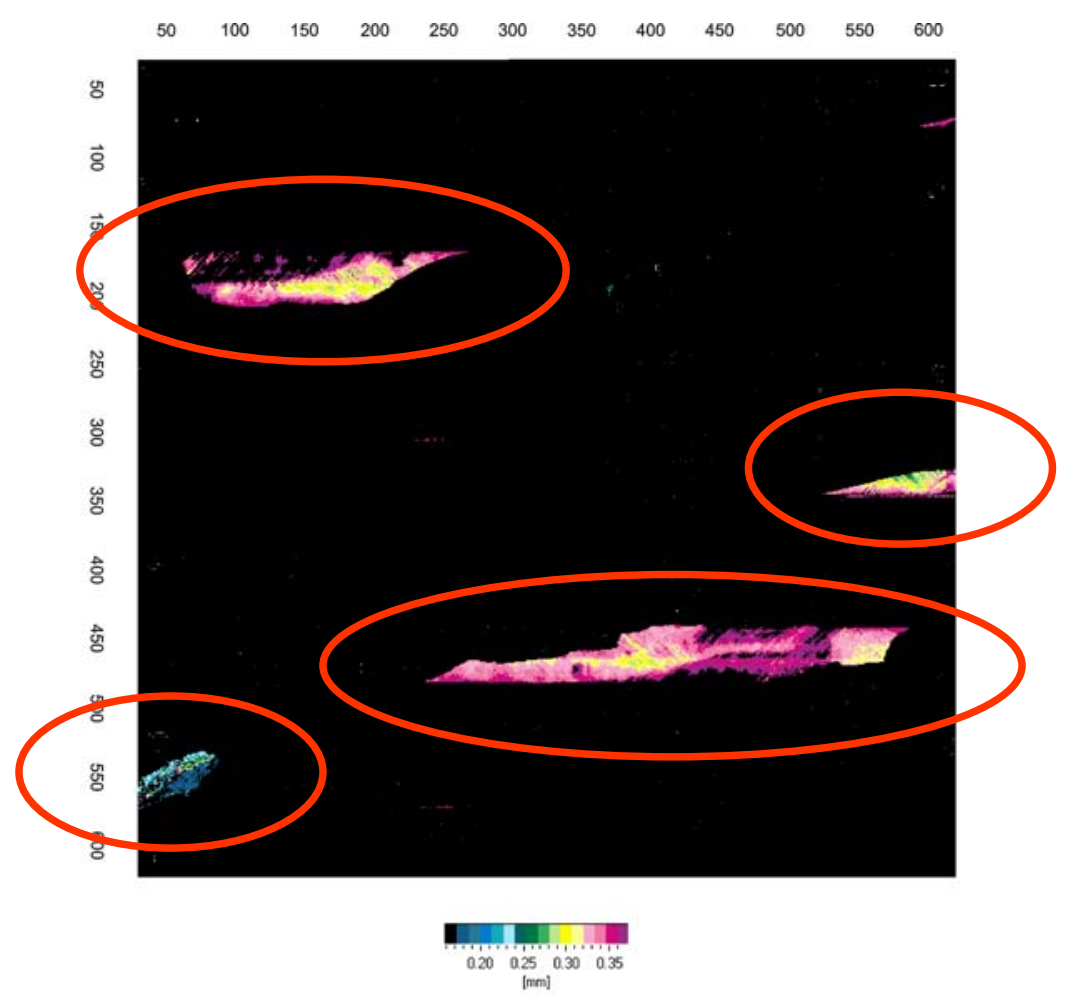

Fig. 6

Ultrasonic flaw depth response of the COCOMAT 6A panel

The other delamination areas discovered by ultrasonic inspection were undetectable by visual observations. Moreover, comparison of the COCOMAT 6A and 6B panel ultrasonic inspection test results shows that the panel $6 \mathrm{~B}$ has been subjected to lower load level than the panel $6 \mathrm{~A}$ and therefore avoided the intensive delamination growth before the collapse of the structure and has no significant damage.

\section{Buckling experiments}

After the ultrasonic inspections of the panels and detection of the hidden delaminations, the panels were assembled for buckling tests. Testing was carried out on INSTRON 8802 servo-hydraulic testing machine, with maximum load capacity of $250 \mathrm{kN}$. For the verification of testing procedure both clamped and simply supported loading conditions have been used. In particular, hinge type sphere with radius of $300 \mathrm{~mm}$ is used to investigate the buckling/post-buckling behaviour change due to different boundary conditions. Both hinged and clamped support tests indicated virtually the same load-shortening responses [1]. Buckling mode shapes, see Fig. 8, have been captured by camera through moiré fringe and strain gauge data has been acquired. Clamped support tests with evolving of buckling and post-buckling mode shapes are presented in Fig. 9 and Fig. 10. Ultrasonic scanning was repeated after the buckling tests and the 
results show that delamination does not propagate in the panel with large delamination zone, when loaded up to $200 \%$ of the skin buckling load.

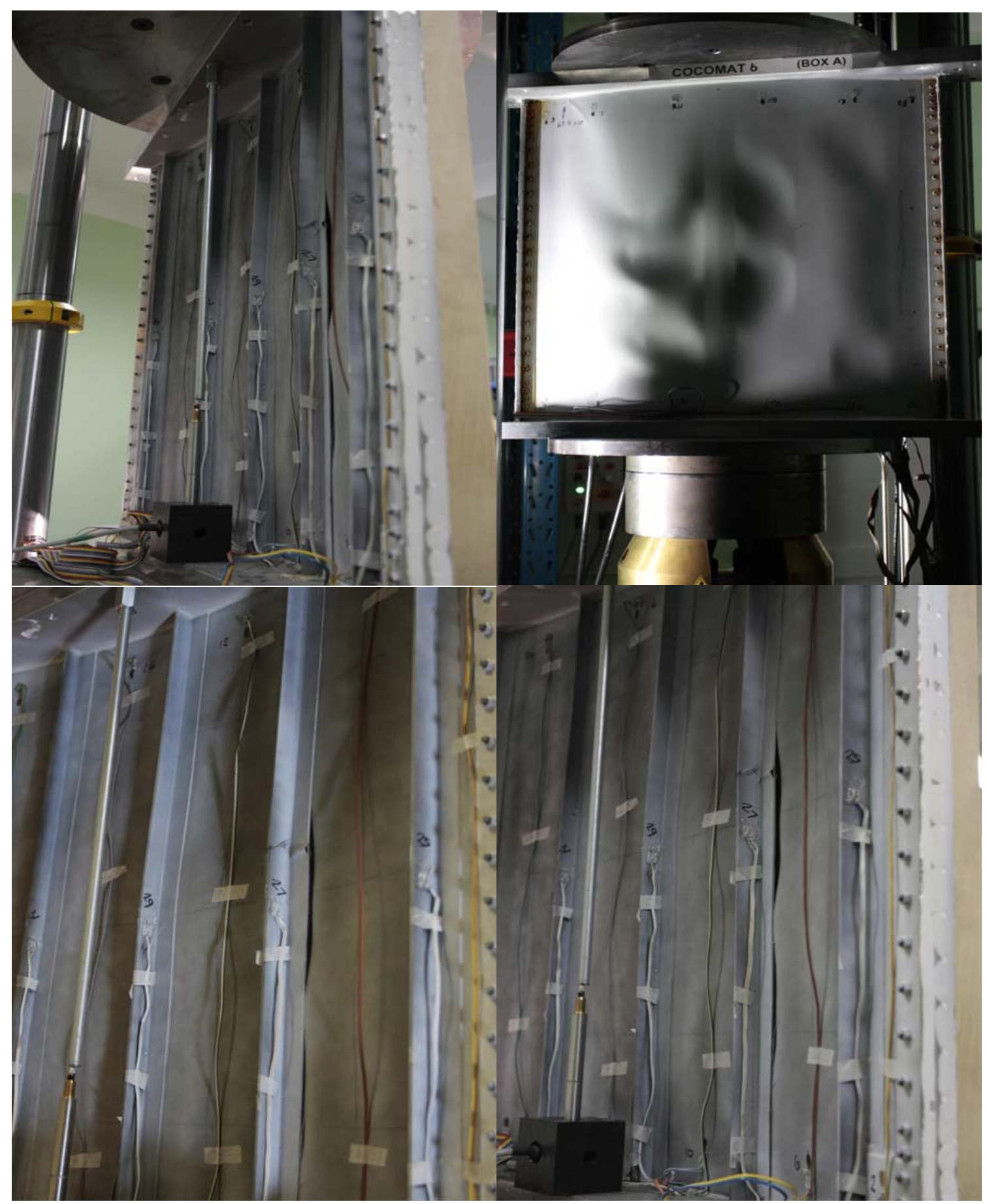

Fig. 7

Delamination presence between the skin and stiffeners COCOMAT 6A 


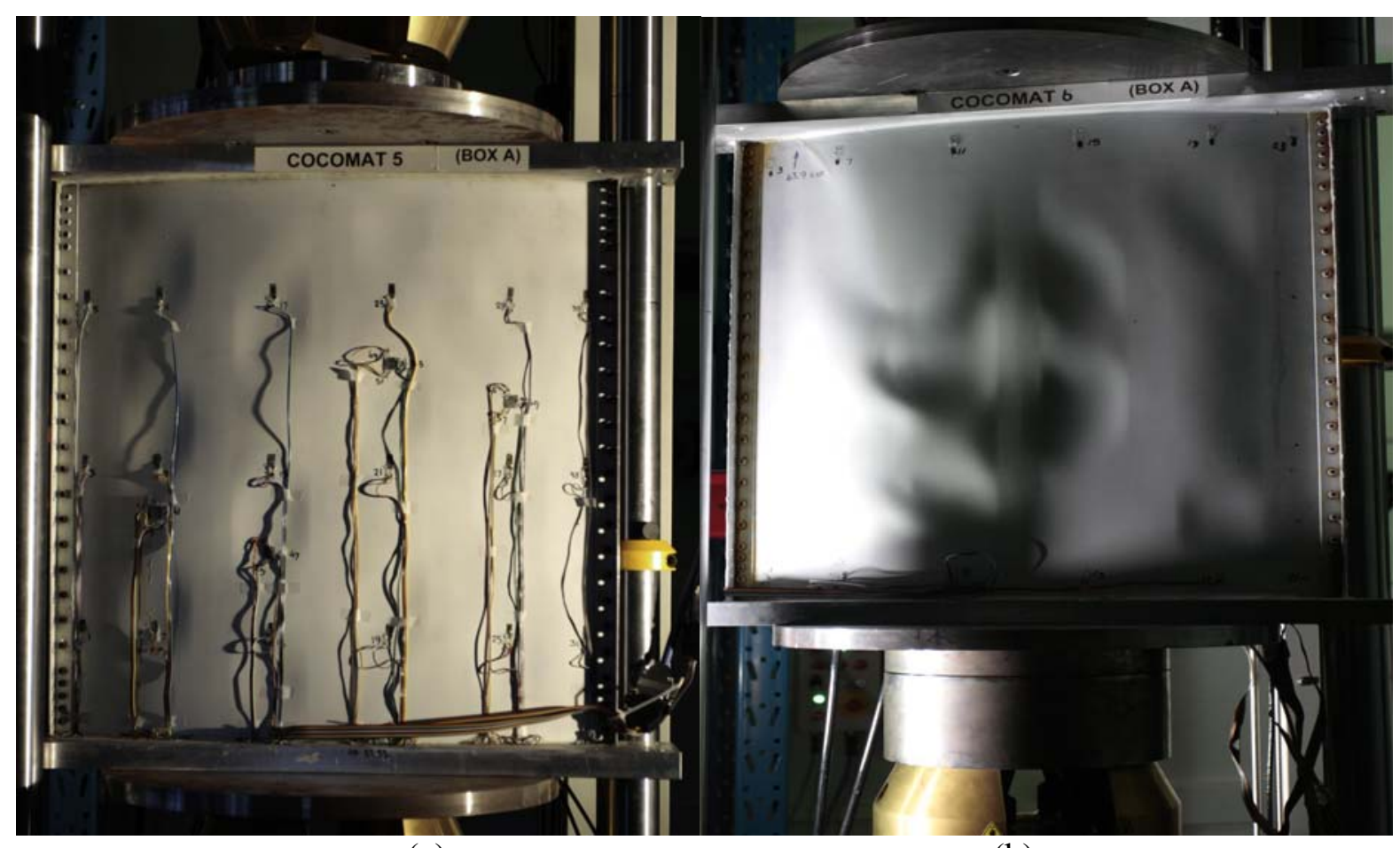

(a)

(b)

Fig. 8

Deformed shape of non-damaged (a) and damaged (b) panels at $115 \mathrm{kN}$ load

As seen in Fig. 8, the panel without damage (a) has more regular buckling mode shape pattern than the one with stiffener delaminations (b). This indicates that the load distributes less uniformly across the panel width in the damaged specimen, thus resulting in stress concentrations, which can lead to further delamination growth or material failure. Stress misbalance can considerably decrease the load carrying capacity of the panel, especially in the post-buckling region.

\subsection{Data acquisition}

Strain gauge data has been acquired using HBM MGCplus data acquisition equipment employing multichannel amplifier designed for capturing data from single, half bridge or full bridge strain gauge setups. Back to back single strain gauge technique was used for detection of buckling initiation. Several strain gauges on the one side of the panel are compared against corresponding strain gauges on the other side of the panel. Pre-buckling phase is clearly identifiable as constantly growing parallel strain slopes, where strains on the both shell sides are equal and only axial compression is observed. At the buckling point, bending of the shell wall is indicated by the change of the strain direction or even sign. Bending of the shell unloads the strain gauge on the tensioned side and adds more strain on the compressed side. During the post-buckling phase strains can suddenly change their signs, this indicates the mode shape change or mode shape movement along the surface of the panel. Load-shortening curves for both damaged and nondamaged panels are presented in Fig. 11.

Strain gauge readings have been taken at the lower edge of the damaged panel between the stiffeners on both sides of the skin and in the middle sections of the non-damaged panel. Strain gauge readings for both panels are presented in Fig. 12 and Fig. 13. 


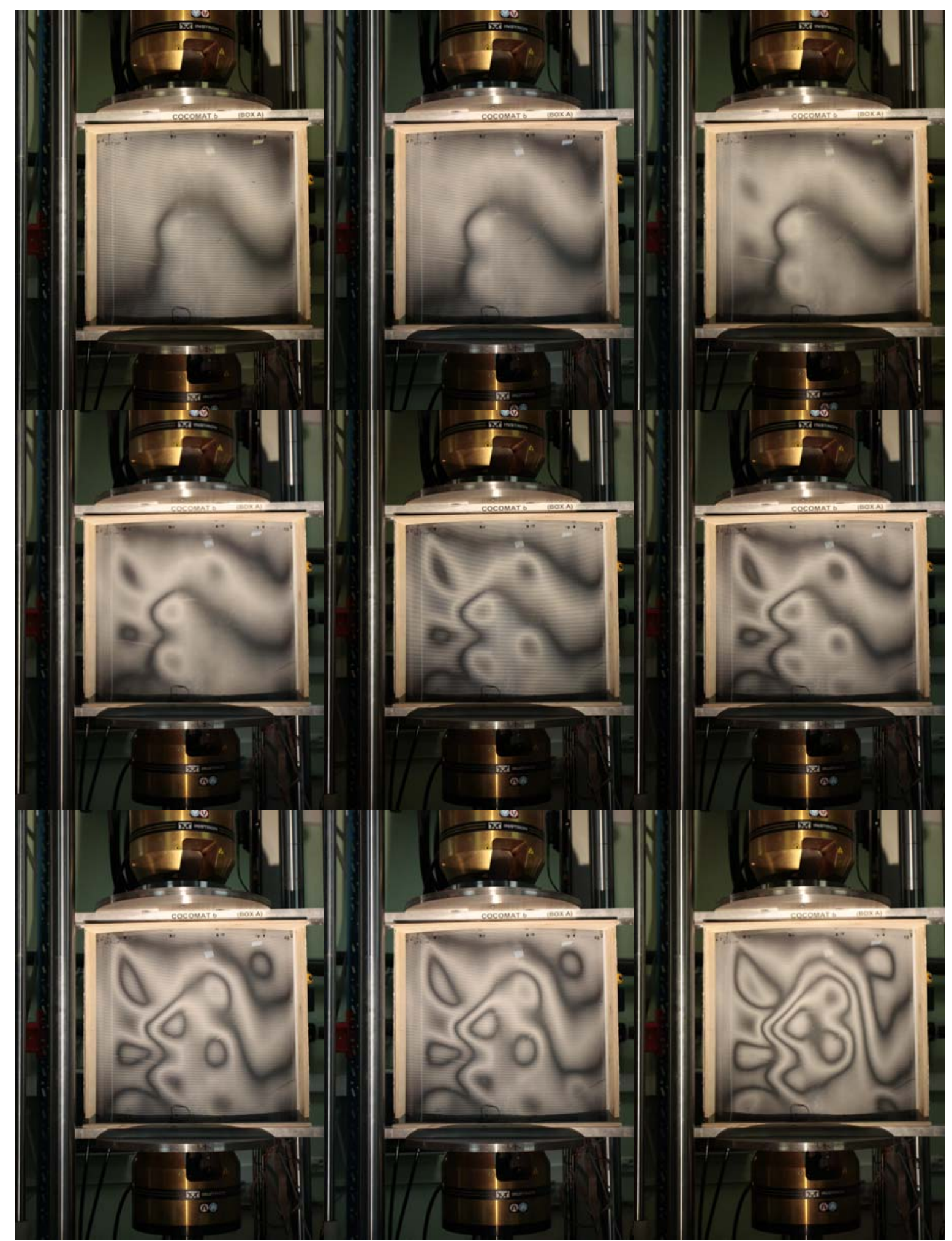

Fig. 9

Evolvement of buckling and postbuckling mode shapes for damaged panel 


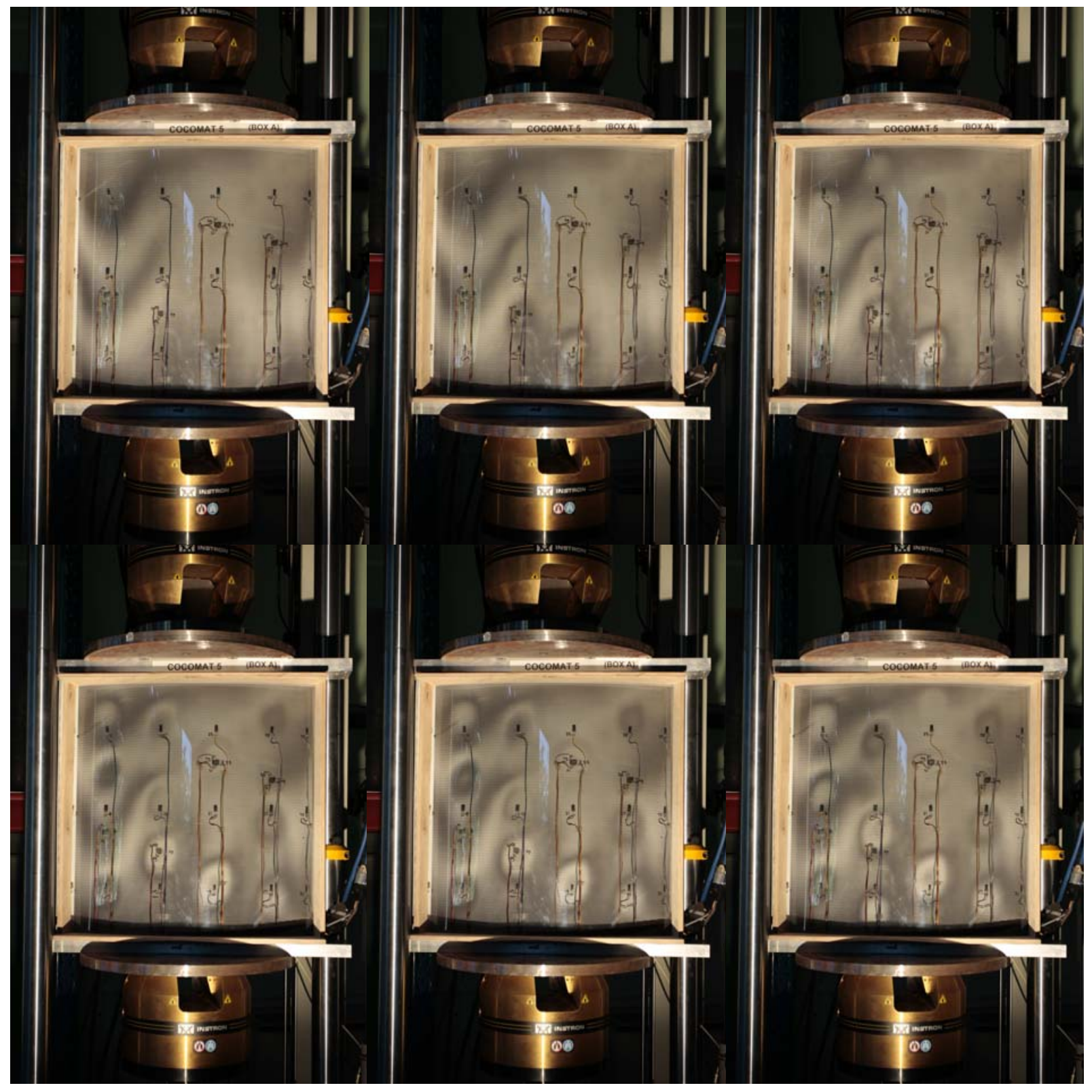

Fig. 10

Evolvement of buckling and postbuckling mode shapes for non-damaged panel 


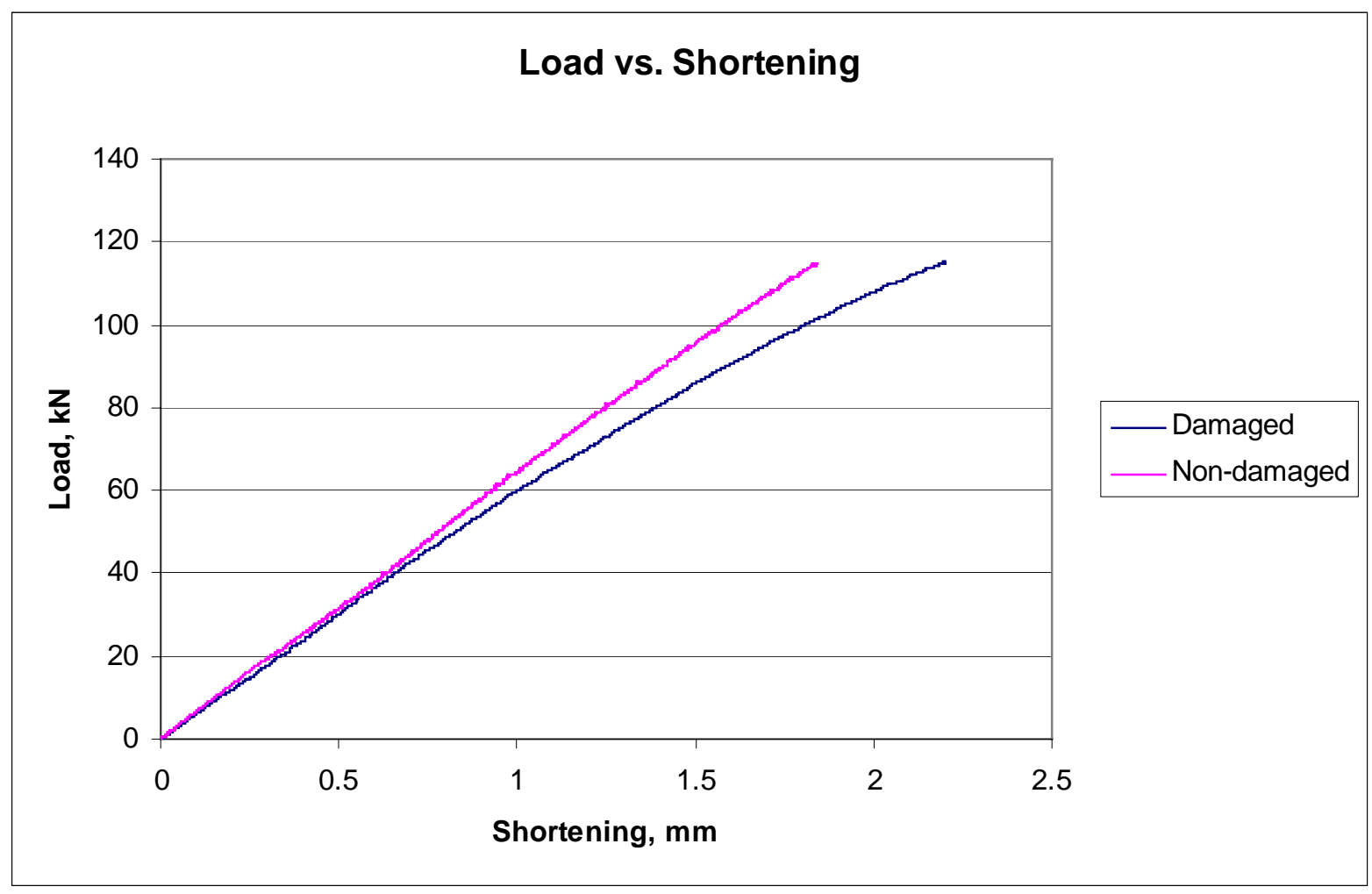

Fig. 11

Load vs. Shortening comparison for damaged and non-damaged panels.

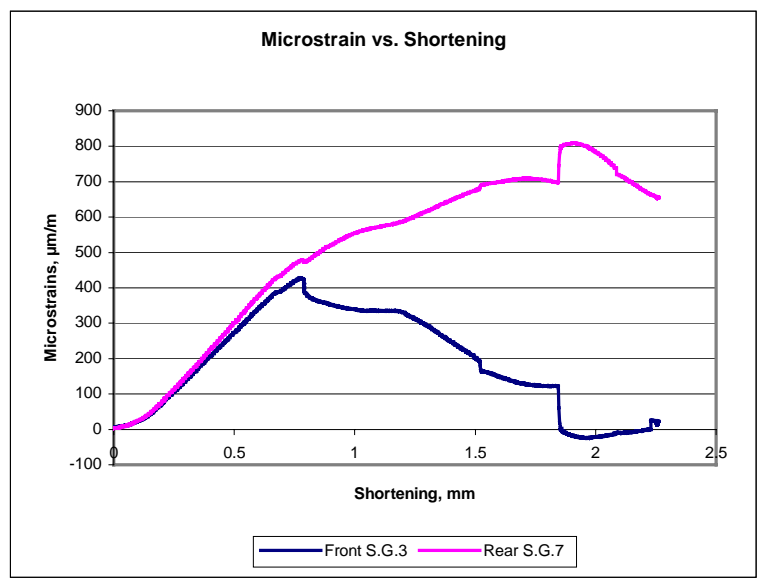

(a)

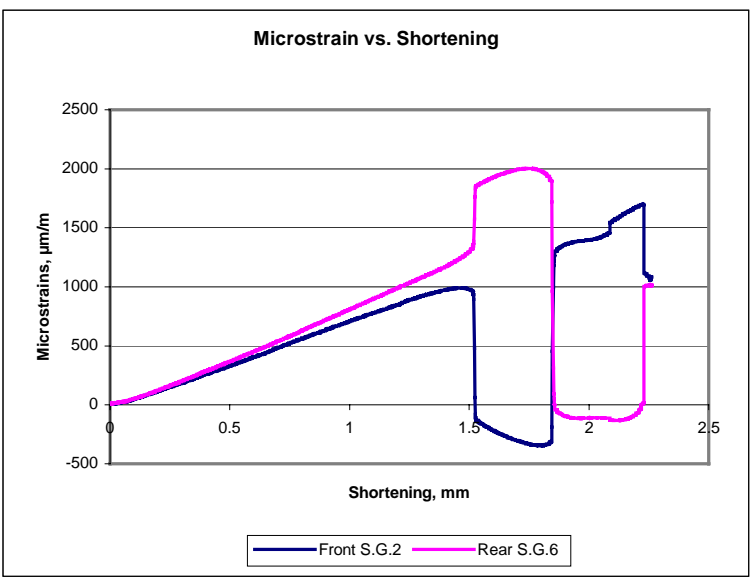

(b)

Fig. 12

Strain gauge measurements in RTU tests of damaged panel 


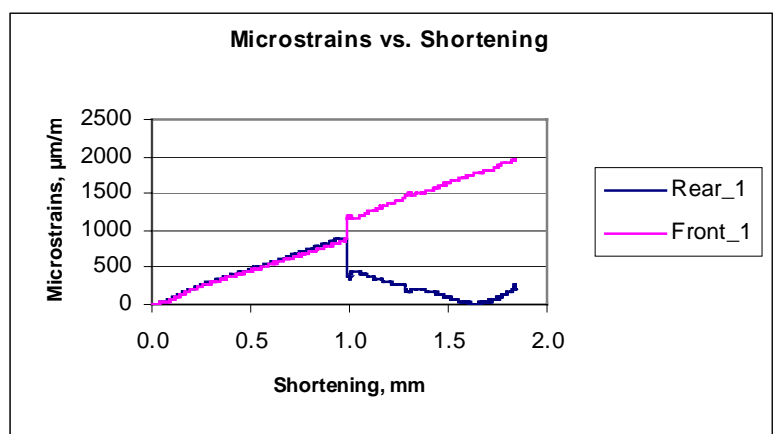

(a)

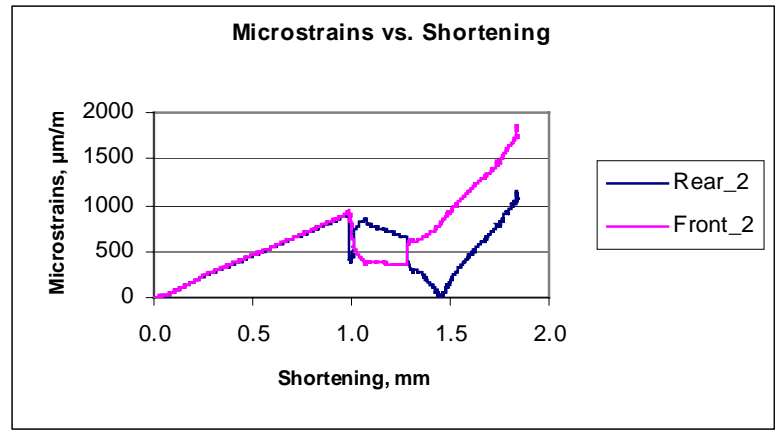

(b)

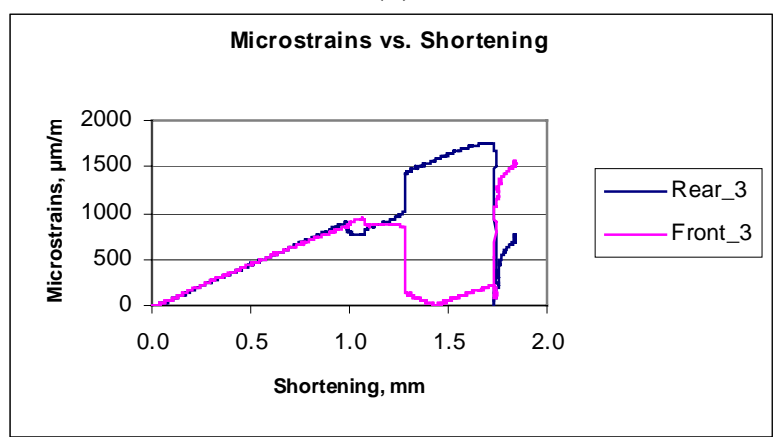

(c)

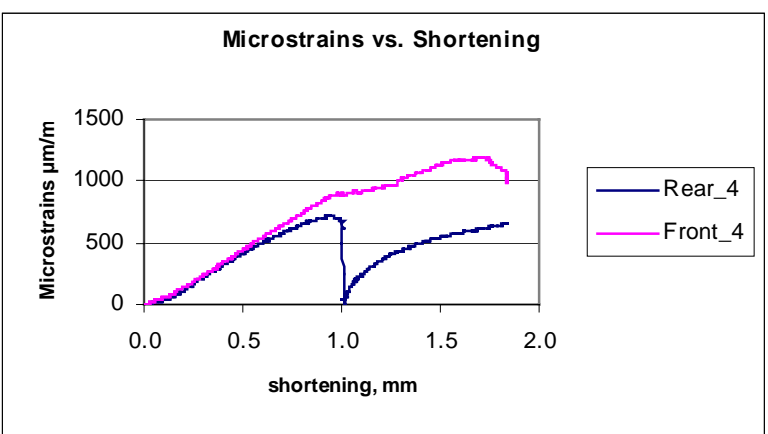

(d)

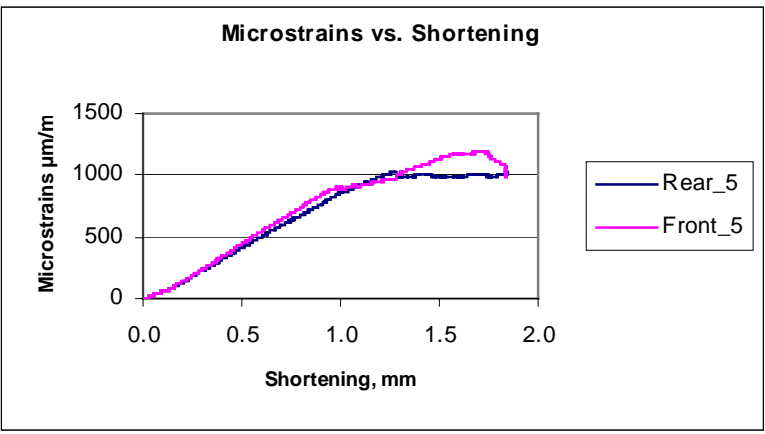

(e)

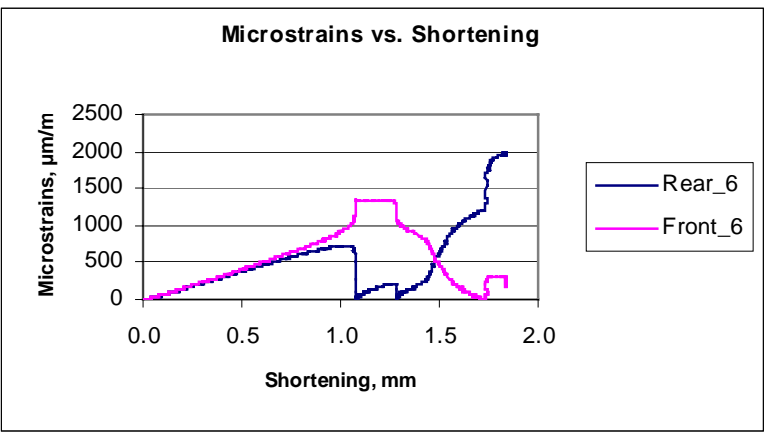

(f)

Fig. 13

Strain gauge measurements in RTU tests of COCOMAT 5 (BOXA) non-damaged panel

Comparison of the panel performance at the $114.5 \mathrm{kN}$ maximum load in post-buckling region and the skin buckling loads is presented in Table 1 . Approximately $16 \%$ of the overall stiffener flange area of the damaged panel had delaminated, as detected by ultrasonic inspections, resulting in decrease of skin buckling load and post-buckling stiffness. At the maximum load applied to the specimens, the damaged panel had shortened $20 \%$ more than the undamaged panel. This is the result of the $35 \%$ decrease in the post-buckling stiffness and $35 \%$ decrease in the skin buckling load.

Despite the decrease in the stiffness characteristics of the structure for the damaged specimen, the buckling occurs at almost identical strain level for both panels, which stays the same through the whole loading range. At the maximum load, the strains recorded by the strain gauges are $6 \%$ lower in the damaged panel than they are in the undamaged one. This can be partly explained by different locations of the strain gauges on the specimens, as explained in the chapter 4.1. 
Comparison in buckling performance of the undamaged and the damaged panel

Table 1

\begin{tabular}{|c|c|c|c|c|c|c|}
\hline Case & \multicolumn{3}{|c|}{ Undamaged } & \multicolumn{3}{c|}{ Damaged } \\
\hline & Load, kN & $\begin{array}{c}\text { Shortening, } \\
\mathbf{m m}\end{array}$ & $\begin{array}{c}\text { Strains, } \\
\boldsymbol{\mu m} / \mathbf{m}\end{array}$ & Load, kN & $\begin{array}{c}\text { Shortening, } \\
\mathbf{m m}\end{array}$ & $\begin{array}{c}\text { Strains, } \\
\boldsymbol{\mu m} / \mathbf{m}\end{array}$ \\
\hline $\begin{array}{c}\text { Maximum } \\
\text { load }\end{array}$ & 114.50 & 1.83 & 1950 & 114.50 & 2.19 & 1830 \\
\hline $\begin{array}{c}\text { Skin } \\
\text { buckling } \\
\text { load }\end{array}$ & 63.00 & 1.20 & 540 & 41.00 & 0.80 & 500 \\
\hline
\end{tabular}

\section{Conclusions}

Two curved, stiffened carbon fibre composite panels have been inspected using non-destructive ultrasonic scanning technique during this study; the amount and locations of the delaminations have been detected. The panels have been loaded with $200 \%$ of the skin buckling load, their post-buckling behaviour has been recorded.

The results of the present investigation show that stiffened composite structures can be successfully exploited up to the buckling load as well as in the post-buckling region of up to $200 \%$ of the skin buckling load, as in case of stiffened panels, which were experimentally tested during this study. Even the previously damaged panel, having $16 \%$ of the stiffener flange area delaminated, carried twice the skin buckling load of the undamaged structure, and no propagation of the delaminations has been observed during the repeated ultrasonic inspection after the buckling test. However, both the skin buckling load and the post-buckling stiffness of the damaged panel were $35 \%$ lower than the corresponding values of the non-damaged panel.

Hereby, there are several limiting factors for exploitation of the composite structures in the post-buckling region and defining a "safe" amount of structural degradation. One of them is deformations of the structure and deformation tolerance of the co-joined structures, e.g. other structures, fittings, communications etc., which should be able to withstand the post-buckling deformations. Otherwise, excess deformations of the buckled structure will destroy co-joined structures far before the collapse. Hereby, the range of acceptable damage should be regarded as problem not only for the panel itself but also for co-joined structures, if present. For this reason more detailed numerical analysis with experimental validation should be carried out for development of the design procedures and prediction of the safe exploitation range.

\section{Acknowledgement}

This study has been partly supported by the European Commission through the FP6 project Improved MATerial Exploitation at Safe Design of COmposite Airframe Structures by Accurate Simulation of Collapse (COCOMAT), by Riga Technical University through the project ZP-2008/3 "Scanning methods for quality control of three-dimensional composite structures" and by Latvian Council of Sciences through the project 09.1262 "Innovative design methodology for manufacturing of composite structures with physical validation" 


\section{References}

1. Natsiavas, S., Babcock, C.D., Knauss, W.G. Postbuckling delamination of a stiffened composite panel using finite element methods // NASA-CR-182803, 1987, $20 \mathrm{p}$.

2. Nilsson, K.-F., Asp, L.E., Alpman, J.E., Nystedt, L. Delamination buckling and growth for delaminations at different depths in a slender composite panel // International Journal of Solids and Structures, Vol. 38, 2001, pp. 3039-3071

3. Gaudenzi, P., Perugini, P., Riccio, A. Post-buckling behavior of composite panels in the presence of unstable delaminations // Composite Structures, Vol. 51, 2001, pp. 301-309

4. Tafreshi, A. Delamination buckling and postbuckling in composite cylindrical shells under combined axial compression and external pressure // Composite Structures, Vol. 72, 2006, pp. 401-418

5. Tafreshi, A. Instability of delaminated composite cylindrical shells under combined axial compression and bending // Composite Structures, Vol. 82, 2008, pp. 422-433

6. Bisagni, C., Cordisco, P. An experimental investigation into the buckling and post-buckling of CFRP shells under combined axial and torsion loading // Composite Structures, Vol. 60, 2003, pp. 391-402

7. http://www.cocomat.de

8. Degenhardt, R., Rolfes, R., Zimmermann, R., Rohwer, K. COCOMAT - Improved MATerial Exploitation at Safe Design of COmposite Airframe Structures by Accurate Simulation of Collapse // Composite Structures, Vol. 73, 2006, pp.175-178.

9. Bisagni, C., Cordisco, P. Testing of stiffened composite cylindrical shells into the post-buckling range until failure // AIAA journal, Vol. 42, 2004, pp. 1806-1817.

10. Kalnins, K., Rikards, R., Auzins, J., Bisagni, C., Abramovich, H., Degenhardt, R. Metamodeling methodology for postbuckling simulation of damaged composite stiffened structures with physical validation // International Journal of Structural Stability and Dynamics, 12 p. (in press)

11. Rikards, R., Chate, A., Ozolinsh, O. Analysis for buckling and vibrations of composite stiffened shells and plates // Composite Structures Vol. 51, 2001, pp. 361-370.

12. Rikards, R., Abramovich, H., Auzins, J., Korjakins, A., Ozolinsh, O., Kalnins, K., Green, T. Surrogate models for optimum design of stiffened composite shells // Composite Structures, Vol. 63, 2004, pp. 243-251.

Oḷgerts Ozoliṇ̆š, M.sc.ing., pētnieks

Riga Technical University,

Institute of Materials and Structures,

Kalku Str. 1, Riga LV 1658, Latvia, olgerts@bf.rtu.lv

Kārlis Dzelzītis, M.sc.ing., pētnieks Riga Technical University, Institute of Materials and Structures, Kalku Str. 1, Riga LV 1658, Latvia, karlisdzelzitis@,inbox.lv

Edgars Eglītis, M.sc.ing., pētnieks Riga Technical University, Institute of Materials and Structures, Kalku Str. 1, Riga LV 1658, Latvia, edgars.eglitis@rtu.lv 
Ozoliņš O., Dzelzītis K., Eglītis E. Eksperimentāls novērtējums bojājumu ietekmei uz ribotu oglekḷa šķiedras kompozīto paneḷ noturību

Oglekḷa šķiedras kompozītos bieži tiek novēroti atslāņošanas bojājumi, kuri pakāpeniski akumulējas pilnīgam konstrukcijas sabrukumam. Deformācijas, ko rada spiediens uz kompozīto fizelāžas virsmu vai noturības zudums, var novest pie atslāņošanas starp paneli un ribām. No otras puses, daudzi pētījumi ir pierādījuši ribotu kompozītu konstrukciju spēju nest slodzi arī pēc noturības zuduma, taču projektēšanas vadlīnijas šo spēju izmantot neparedz. Eksperimentāli bojājumu ietekmes uz ribotas čaulas veiktspēju pēcnoturības apgabalā pētījumi ir nepieciešami jaunu projektēšanas vadlīniju izstrādei, kas piel̦autu drošu kompozīto konstrukciju pēcnoturības izmantošanu. Š̆ pètījuma rezultāti parāda, ka pat bojāts ribots oglekl̦a šķiedras kompozīta panelis ir spējīgs uzņemt slodzi, kas ir divas reizes lielāka par kritisko bez tālākas bojājumu izplatīšanās. Tas var tikt izmantots par pamatu turpmākiem, padziļinātiem skaitliskiem un eksperimentāliem pētījumiem šajā jomā ar nolūku uzlabot ribotu kompozīto konstrukciju projektēšanas vadlīnijas.

\section{Ozoliņš O., Dzelzītis K., Eglītis E. Experimental evaluation of damage influence on buckling performance of stiffened CFRP shells \\ Delamination type failures are often observed in carbon-epoxy composites, where catastrophic failure is generally preceded by constituent level damage accumulation. Out-of-plane loading such as internal pressure in a composite fuselage or out-of-plane deformations in compression-loaded post-buckled panel may lead to debonding of the frame or stiffener from the panel. On other hand, numerous investigations show the ability of stiffened composite structures to work in the post-buckling region, which is considered unsafe in the conventional design procedures. Experimental evaluation of damage influence on post-buckling performance of stiffened shells is essential for development of safe design guidelines that would allow exploitation of these structures in the post-buckling region. The results of this investigation show that a damaged stiffened composite shell can be loaded up to 200\% of skin buckling load without any propagation of delaminations. This can serve as the base for more extended studies on the subject, including numerical modelling and improvement of the existing design guidelines.}

Озолиньш О., Дзелзитис К., Эзлитис Э. Экспериментальное определение влияния поврежденний ребристой оболочки из углепластика на потерю устойчивости.

Расслоение углепластиковых композитов - один из наиболее встречаемых видов поврежденний, которые возникают в следствие накопления дефектов. Поперечные деформации от внутреннего давления или потеря устойчивости под действием сжимающей нагрузки могут привести к разрушению соединения между каркасом или ребром жесткости с панелю композитного фюзеляжа. С другой стороны, многие исследованния показывают способность ребристых композитных оболочек работать в закритической области. Экспериментальная оценка влияния поврежденний на потерю устойчивости и закритическое поведенние упрочненной оболочки необходима для созданния руководства по проектированнию конструкиий способных безопасно работать в закритической области. Результаты данных исследований показывают, что ребристые композитные конструкции даже при наличии поврежденний способны выносить нагрузки в размере $200 \%$ от критической без дальнейшей деградаџии. Это может служить основой для дальнейшего изучения вопроса, включая численное моделированние, с целью усовершенствования существуюших руководств по проектированнию. 